\title{
SYMPOSIUM ON GLOBAL ANIMAL LAW, PART II: THE CASE FOR GLOBAL LEGAL ANIMAL STUDIES
}

\section{CROSS-BORDER FORMS OF ANIMAL USE BY INDIGENOUS PEOPLES}

\author{
Stefan Kirchner*
}

The aim of this essay is to show how international law relates to the interaction of indigenous peoples and animals across international borders. While colonial borders have affected the lives of herding communities in Africa and while there are cross-border indigenous activities in different parts of Latin America, the situation in Northern Europe is particularly noteworthy. This is because cross-border activities are possible there not simply because effective border controls are difficult to ensure in such remote areas but mainly because several of the relevant states have the long-term political will to allow for cross-border activities. Particular attention will be given to the situation of the indigenous Sámi people. Their homeland, Sápmi, is governed by Norway, Sweden, Finland, and Russia. The borders between Norway, Sweden, and Finland have been open since the Nordic Passport Union of 1952, significantly predating the Schengen Agreement of 1985, which allows for unhindered travel in large parts of Europe, including these countries. ${ }^{1}$ Finland and Sweden are members of the European Union, while Norway is part of the European Free Trade Area and of the Schengen Agreement; Russia imposes visa requirements on citizens of the three other states. With such limitations, the Russian part of Sápmi is effectively cut off from the Western parts. While the borders between Finland, Norway, and Sweden have long been open for many purposes, this openness does not fully take into account the needs of the indigenous Sámi people, who consider themselves to be one people and consider the Sápmi homeland as a whole. ${ }^{2}$ Today, only part of their ancestral homeland is recognized as Sámi home areas in the legal sense of the term and the Sámi are a minority in their own regions virtually throughout Sápmi. The transnational characteristic of the Sámi people serves to illustrate some of the challenges faced by indigenous peoples with traditional activities such as animal herding as a result of borders imposed on them by the nation states that govern their homelands, yet in which they usually constitute only a small minority.

\footnotetext{
* University Researcher for Arctic Law, Arctic Centre, University of Lapland, Rovaniemi, Finland. The author thanks Sámi friends and colleagues from Sweden and Finland for their insightful information about Sámi liveliboods. All opinions and errors contained in this text are only attributable to the author.

${ }^{1}$ The Schengen acquis as referred to in Article 1(2) of Council Decision 1999/435/EC of 20 May 1999, Agreement between the Governments of the States of the Benelux Economic Union, the Federal Republic of Germany and the French Republic on the gradual abolition of checks at their common borders, 2000 O.J. (L 239) 1,13-18 (Agreement between the Governments of the States of the Benelux Economic Union, the Federal Republic of Germany and the French Republic on the gradual abolition of checks at their common borders of September 22, 2000); for the implementation of the Schengen agreement see the Convention implementing the Schengen Agreement of 14 June 1985 between the Governments of the States of the Benelux Economic Union, the Federal Republic of Germany and the French Republic on the gradual abolition of checks at their common borders, $\underline{i d}$. at 19-26; for the accession to the latter by Finland and Sweden see $\underline{i d}$. at 106-14 and 115-23, respectively.

${ }^{2}$ Cf. The Sami of Northern Europe-One People, Four Countries, UN Regional Information Centre for Western Europe.
}

The American Society of International Law and Stefan Kirchner (C) 2017. This is an Open Access article, distributed under the terms 402 of the Creative Commons Attribution licence (http://creativecommons.org/licenses/by/4.0/), which permits unrestricted re-use, distribution, and reproduction in any medium, provided the original work is properly cited. 


\section{Traditional Livelihoods of a Transnational Indigenous People}

Reindeer herding is an important source of income for many indigenous communities in the Arctic and Subarctic, ${ }^{3}$ especially in the Nordic countries and Russia. Reindeer are owned but for almost all practical purposes are free to roam large, but delimited, areas. In Norway and Sweden the human-reindeer interaction involves seasonal migration between summer pastures at higher altitudes and winter pastures closer to the sea.

In Norway and Sweden only indigenous persons have the right to herd reindeer, whereas every EU citizen, enjoying the freedom to work across borders, is free to own and herd reindeer in Finland. In Sweden, the right to herd reindeer is held by the local sameby, the Sámi Village. While serving as a reminder of the traditional Sámi unit of organization, the siida, these entities, despite their name, have been created by the state for the purpose of managing the right to herd reindeer. Each sameby holds the right to herd reindeer in a long thin strip of land, generally ranging from the mountains in the West to the sea in the East. While there are still many parallels to traditional Sámi forms of organizing and managing reindeer herding, the framework for reindeer herding is controlled by the state rather than by indigenous communities.

In Finland, indigenous reindeer herding families are even more constrained by the legal framework created by the state: reindeer herding is organized through reindeer herding associations (paliskunnat). ${ }^{4}$ Within a paliskunta, decisions are made by the majority, but because nonindigenous persons may herd reindeer, too, it is possible for Sámi reindeer herders to be in the minority. As a result, the traditional ways of herding reindeer have been abandoned in many paliskunnat. In one paliskunta, the nonindigenous majority sets the numbers of reindeer to be slaughtered, which effectively forced indigenous reindeer herding families in one part of the paliskunta to slaughter all of their reindeer. ${ }^{5}$

As a result of the national regulation of reindeer herding, today there is no longer any transboundary reindeer herding in Sápmi: while the free movement of persons is permitted under the Schengen Agreement and many people in the region cross borders on a regular basis, reindeer herding is regulated on the national levels. This has long been a problem for Sámi reindeer herders. ${ }^{6}$

This indicates a stronger role for the nation state in a region which has long been defined by shared cultures rather than borders. Centuries ago, the Sámi were taxed by different sovereigns. Today, although their way of life has not been entirely robbed of its transnational dimension, their best-known traditional livelihood has been restricted by borders that were created without the doing of the indigenous communities affected. Despite the fact that most Sámi depend primarily on other sources of income, reindeer herding remains an important part of Sámi culture.

\section{Involving Indigenous Peoples in Decision-Making Processes and Protecting their Rights in International Agreements}

One important problem of indigenous rights in the Arctic is the involvement of indigenous communities in decision-making processes. Today, national Sámi parliaments in Norway, Sweden, and Finland play important roles in giving the Sámi people a voice on the national level, for example, in the context of mining permits.

\footnotetext{
${ }^{3}$ Irina L. Stoyanova, The Saami Facing the Impacts of Global Climate Change, in Climate Change and Indigenous Peoples-The Search for Local Remedies 287, 291 (Randall S. Abate \& Elizabeth Ann Kronk Warner eds., 2014).

${ }^{4}$ For further details, see Tero Mustonen \& Gwyn Jones, Reindeer Herding in Finland: A Report for Trashumancia y Natraleza 4-8 (European Forum on Nature Conservation and Pastoralism, June 2015).

${ }^{5}$ UN Human Rights Comm., Kalevi Paadar et al. v. Finland, Communication No. 2102/2011 of 10 April 2014, UN Doc. CCPR/C/110/ D/2102/2011 (Apr. 10, 2014).

${ }^{6}$ See J.G. Elbo, The Norwegian-Finnish Reindeer Fence, 7 Polar Rec. 73 (1954).
} 
However, the rights of indigenous peoples are at risk of being ignored by national governments engaging in international relations.

For example, the lack of Sámi participation was criticized recently in the context of the Deatnu River Agreement between Finland and Norway, which, has not yet entered into force at the time of writing. ${ }^{7}$ The Deatnu River (Finnish: Tenojoki, Norwegian: Tanaelva) forms part of the border between Finland and Norway in the homeland of the Sámi people. Next to reindeer herding, fishing is a key traditional livelihood of the Sámi people. The Deatnu River is one of the best salmon rivers worldwide and attracts tourists from around the world due to its remarkable water quality and the size of the salmon caught there. This sets the stage for a usage conflict between indigenous and nonindigenous actors. The agreement between Finland and Norway restricts traditional indigenous fishing rights in the Sámi heartland which de facto allows for the development of fishing-based tourism in the region. While fishing and tourism are important sources of income for this region of Europe, fishing is a crucial element of Sámi culture as well. This is particularly so not only along the coasts but especially in the northeastern part of Finland and in Norway. By agreeing on the distribution of the right to fish in the border river without taking sufficient account of the local indigenous communities, Finland and Norway risk violating the rights of the indigenous Sámi to be heard, their right to be consulted (under International Labour Organization Convention No. 169 for Norway and, arguably more far-reaching, under customary international law for Finland, which has not yet ratified the Convention), and their right to engage in sustainable livelihoods.

One notable exception to the lack of Sámi participation is the Sámi Parliaments' role in drafting the proposed "Nordic Saami Convention" ("Saami" is an alternative spelling for "Sámi"). The need for a regional treaty arose due to the limited protection of indigenous rights under existing norms, as the next paragraphs will explain.

The transnational reality of Sámi identity is not recognized in international law, a problem this group shares with many other transnational indigenous peoples. In general, unlike in the Inter-American human rights system, indigenous rights have hardly played a role at the European Court of Human Rights. ${ }^{8}$ The European Convention on Human Rights (ECHR), which has been ratified by the four states in question, only protects indigenous livelihoods in the context of the right to private life (Article 8 ECHR). ${ }^{?}$

Some Sámi litigants have sought protection of their rights under Article 27 of the International Covenant on Civil and Political Rights (ICCPR), also ratified by the four states, and some work has been undertaken in Europe on national minorities. Article 27 ICCPR remains a norm of central importance in the context of indigenous rights, especially as the International Labour Organization Convention No. 169 has not been ratified by key states in the region, including Sweden, Finland, and Russia, and the 2007 UN Declaration on the Rights of Indigenous Peoples (UNDRIP) (which in large parts reflects the existing customary international law) is nonbinding as it was adopted by the UN General Assembly. The importance of Article 27 ICCPR is reflected in the range of cases in which it has been invoked, many of which originated from Sápmi. According to Article 27 ICCPR, minorities, including indigenous communities, have the right to enjoy their culture. This has long been understood to include cultural activities which have the purpose of making a living, including reindeer herding for profit. The wording of Article 27 ICCPR, which dates back to the 1960s, however, shows that existing international human rights norms are still too dependent on the current statecentered system of international law in order to fully take into account the needs of transnational indigenous peoples: the rights under Article 27 ICCPR only apply "[i]n those States, in which ethnic, religious or linguistic minorities exist." ${ }^{10}$ There is no transnational element in Article 27 ICCPR which would allow for cross-border reindeer herding.

\footnotetext{
${ }^{7}$ This text is up to date as of November 15, 2017.

${ }^{8}$ But see, e.g., Timo Koivurova, Jurisprudence of the European Court of Human Rights Regarding Indigenous Peoples: Retrospects and Prospects, 18 INT'L J. Minority \& Group Rts. 1 (2011).

${ }^{9}$ See G. and E. v. Norway, App. Nos. 9278/81 and 9415/81 (1983 Eur. Comm'n on H.R.).

${ }^{10}$ International Covenant on Civil and Political Rights art. 27, Mar. 23, 1976, 999 UNTS 171.
} 
The United Nations Declaration on the Rights of Indigenous Peoples could have been an important step towards closing this gap-and the development of customary international law in the years since then is not to be underestimated - but the UNDRIP was adopted "only" by the General Assembly of the United Nations. It therefore is not a binding document per se. While the UNDRIP is contributing to the development of customary international law, codifications, especially "user-friendly" codifications, are a hallmark of the legal systems of the Nordic states. It is therefore hardly surprising that there has long been a desire to clarify in a written instrument the legal situation of the Sámi people across borders.

Today, even the definition of who is actually Sámi varies between the states because the states have set different criteria for the eligibility to participate in the elections to the respective national Sámi parliaments. In recent years, negotiations have been underway between Norway, Finland, and Sweden to establish an international treaty, the Nordic Saami Convention, to unify the legal position of the Sámi people at least in three of the four countries in question. The national Sámi parliaments played an important role in the drafting process, thereby expanding the realm of consultation of indigenous communities from the national to the transnational-in accordance with the cultural reality of the Sámi people, who consider themselves to be one people, regardless of languages and passports.

The attempt at involving indigenous representatives in the making of a new international treaty is a laudable development, but due to the long passage of time during which reindeer herding has already been regulated on the national level and within national borders, this move might come too late for Sámi reindeer herders. At this time, a revival of old — sustainable - patterns of reindeer herding, regardless of national borders, appears if not impossible then at least highly unlikely. The revival of some Sámi languages in recent years has been an important cultural development, but the recognition of traditional ways of reindeer herding appears to face too many obstacles, not least in the form of competing land use claims, to be a realistic option in the foreseeable future.

In the case of the fishing rights in the Deatnu river, which forms the border between Norway and Finland, it would have been much easier for the two nations, which have long enjoyed excellent relations, to come to a solution which would have allowed the realization of transnational animal use rights by the Sámi people living on both sides of the river. This opportunity was not only missed when the economic interests of the nation states areas were given precedence over indigenous needs and traditions, but also when both states failed to let the affected Sámi people weigh in sufficiently.

\section{Animals, Welfare, Animal Welfare, and Indigenous Culture}

The failure of states to adequately involve transnational indigenous communities in decision-making processes can also have an impact on the welfare of the animals in question. This is particularly the case when the state imposes ways of handling animals which are at odds with methods that have long been known to be sustainable and holistic, in the sense that they might be beneficial for the overall herd and the community. This, however, does not mean that indigenous approaches are always best from the perspective of the welfare of the individual animal. The approach taken by indigenous communities that depend on animals for their survival is usually dominated by pragmatism rather than contemporary animal welfare discussions. Reindeer herding remains an important element of Sámi culture even though today many indigenous persons have other sources of income. Not only is reindeer meat a regionally important source of food, many traditional products are made from reindeer parts — such as antlers or hide.

That said, often the way that Sámi communities treat animals is significantly closer to the needs of animals than factory-based meat production would allow. For example, unlike caribou in North America, ${ }^{11}$ reindeer in Sápmi

11 See Caribou Hunting in Alaska, Alaska Department of Fish and Game. 
are no longer hunted ${ }^{12}$ but herded. ${ }^{13}$ The animals are owned by the herders but not fully domesticated in the same way as farm animals are. Far from it, they roam large areas fairly freely and are only collected in autumn ${ }^{14}$ or, in Sweden and Norway, during the seasonal migrations between summer and winter pastures. ${ }^{15}$ For Sámi reindeer herders, the wellbeing of the animals is essential for their own wellbeing. Indeed, meat production is only one purpose of reindeer herding; other parts of the animals are used for the production of culturally relevant products. The cultural, not merely practical, importance of caring for reindeer differentiates this form of animal use from other animal-related livelihoods, including ranching, hunting, or fishing. Indeed, economic profit was never a main goal of reindeer herding. In addition to providing food security, the cultural dimension of hunting, herding, and fishing is not to be underestimated. Often key animals take on a highly symbolic value for indigenous cultures. Especially for (semi)nomadic indigenous communities, as commonly found in the Arctic and Subarctic, gatherings are associated with traditional forms of animal-related livelihoods. For transboundary (semi)nomadic indigenous peoples like the Sámi, such gatherings are also important cultural events. By reorganizing the traditional cultural activity of reindeer herding within different national legal frameworks, not only the traditional way of life but also the culture of the indigenous Sámi people has been affected.

The situation in Sweden illustrates rather dramatically the need for national lawmakers to respect traditional cultures as all indigenous land rights are dependent on reindeer herding, Swedish law not recognizing other forms of indigenous land rights, e.g., for fishing. In Finland, the right to herd reindeer is not even restricted to indigenous persons or groups but in theory every EU citizen can join a reindeer herding association. Other concerns are even more pressing from the perspective of indigenous reindeer herders: while climate change is a longterm problem, the more immediate threat to both animals and indigenous reindeer herders stems from increased land use conflicts. Mining, forestry, and the construction of infrastructure not only take away the possibility for reindeer to roam freely, they also endanger the natural environment and reduce food security for the animals and therefore also for the Sámi reindeer herders. Animal welfare is scarcely taken into account, which might also be due to a lack of information among decision-makers in Stockholm, Oslo, and Helsinki despite the significant extent of scientific research on reindeer.

\section{Concluding Remarks}

Animals play important cultural, economic, and spiritual roles for indigenous communities. However, contemporary law does not go far enough in recognizing this particular form of interaction between humans and animals. Treating indigenous livelihoods like farming or ranching like nonindigenous counterparts means that significant cultural aspects are overlooked and that indigenous knowledge regarding the wellbeing of animals is often disregarded by political decision-makers. Climate change and increased land uses already threaten traditional ways of life in the North. The situation is worsened by the continued separation of the Sámi people by state borders. Today, there is no single form of Sámi reindeer herding but instead there are stark differences between the four states. The same applies to a great extent to fishing. The borders between the countries governing Sámi (with the exception of

\footnotetext{
${ }^{12}$ On historic Sámi reindeer hunting, see Jonathan Snatic, Hunting and Gathering by the Sami, SAmi Culture. Elsewhere, hunting and poaching remain a serious threat to the survival of reindeer, for example on Russia's Taimyr peninsula. See How Poaching Is "Killing Off" the World's Largest Reindeer Herd on Taimyr Peninsula, Siberian Times (Feb. 7, 2017).

${ }^{13}$ Cf. Jan Åge Riseth et al., 175 Years of Adaptation: North Scandinavian Sámi Reindeer Herding Between Government Policies and Winter Climate Variability (1835-2010), 24 J. Forest ECON. 186 (2016).

${ }^{14}$ Mustonen \& Jones, supra note 4, at 3.

15 A somewhat similar approach to herding is also found among some shepherding communities in Britain's Lake District. See JAMES Rebanks, The Shepherd's Life: A Tale of the Lake District 9 (2d ed. 2016).
} 
Russia) were opened in the twentieth century. Yet, similar to the situation in North America despite the 1794 Jay Treaty, the borders are still very real for indigenous peoples. The way of life of many indigenous communities is dependent on the behavior of animals. Migratory animals are not constrained by international borders. In many places around the world, pastoralist (semi)nomadic herding has conflicted with sedentary agriculture for many centuries. Today, conflicts between settlers and indigenous communities are usually understood from the perspective of the dominant part of society, that is, the settler community (many members of which are unaware of the historical background and the land rights of indigenous peoples). In many cases, such conflicts turn on the needs of different animals, for example free-ranging reindeer as opposed to grazing cattle or other animals usually associated with farming. Through the dominance of the settler society, the needs of farming-and ranching-related animals, as well as other interests such as the construction of infrastructure and other economic activities that require land, are given precedence over the interests of wild or semidomesticated animals on which the livelihoods of indigenous people depend. Often specific indigenous needs are seen as conflicting with the interest of the state, which means that politically, indigenous interests can be framed as conflicting with what is perceived as the "common" good.

This risk is particularly acute in the Nordic countries due to a political and legal emphasis on equality, which leads to widespread political opposition to what is perceived as additional rights for special interest groups. While this is changing, the move towards better protection of indigenous rights is not a straightforward process. Discrimination against Sámi persons is still widespread, despite the general commitment to human rights in Norway, Finland, and Sweden. A limited recognition of indigenous rights also has direct effects on the wellbeing of animals associated with indigenous communities. 